\title{
Investigating Iranian English Language Teachers' Practices and Perceptions of Vocabulary Teaching
}

\author{
Sara Mirzaie \\ Payame Noor University, Iran \\ Fatemeh Hemmati \\ Payame Noor University, Iran \\ Mohammad Aghajanzadeh Kiasi \\ Payame Noor University, Iran
}

\begin{abstract}
This study aimed at exploring English language teachers' practices and perceptions of vocabulary teaching in Iranian private language schools. Using a qualitative research design, four competent language teachers were purposefully selected and their perceptions of vocabulary teaching were investigated from several dimensions. Three qualitative data gathering techniques including interviews, classroom observation, and stimulated recall interviews were utilized to have a thorough understanding of the participants' practices and perceptions about vocabulary instruction. Findings revealed that although EFL teachers possessed sufficient knowledge and perspectives with respect to vocabulary teaching strategies, such stated declarative knowledge did not serve the full purposes of vocabulary teaching. Participants typically utilized decontextualized strategies more extensively than contextualized ones in their actual practices indicating that their tendencies are somehow towards traditional approaches in teaching vocabulary. In other words, teachers' instructional practices did not capture all their stated beliefs. Furthermore, it was found that the implemented policies in English language schools which are greatly towards time economization might be a liable reason cheering teachers to deviate from their real beliefs. Finally, contributing to developmental aspects of language teaching, findings of this particular study possess several implications both for teacher education institutions and stakeholders in private language schools in Iran and other similar contexts.
\end{abstract}

Index Terms-teachers' perception, vocabulary instruction, vocabulary teaching strategies, contextualized strategies, decontextualized strategies

\section{INTRODUCTION}

Knowledge of vocabulary is frequently seen as a basic apparatus for L2 language learners on the grounds that a restricted repertoire of vocabulary hinders fruitful communication (Nation, 2011 \& Schmitt, 2000). Meara (1980) states that even after the early stages of learning a second language, most of language learners identify vocabulary as their utmost single source of problems. According to Oxford (2003, p.9), "Skilled teachers help their students develop an awareness of learning strategies and enable them to use a wider range of appropriate strategies". Several scholars (Bachman \& Palmer, 1996; Bialystok, 1990; Chamot \& O’Malley, 1996; Cohen, 1998; Green \& Oxford, 1995; Oxford, 2003) highlight the significance of strategies for an effective language teaching and learning. Consequently, to empower learner's proficiency level relevant to their needs, it is considerably more imperative for the language teachers to employ compelling and dynamic teaching strategies that will engage learners to master the required tasks and this can be established through teacher's practices and their instructional approaches in the classroom. Moreover, practices teachers perform in the milieu of classrooms are usually based on their perceptions and understandings of teaching and learning. Such perceptions are often described as propositions of mind that determine teachers' behaviors, from both psychological and educational perspectives (Debreli, 2011; Ghanizadeh \& Jahedizadeh, 2015) and essentially affect their classroom practices, professional growth, instructional objectives, classroom collaboration designs, teaching strategies, etc. all of which consequently affect their learners and the whole school success (Harste \& Burke, 1977; Ramazani, 2013). From this perspective both teachers' practices and perceptions may accelerate or impede the success of any educational reform (Woodrow, 1991).It seems that both issues are pivotal based on which teacher educators can adjust their programs with central educational objectives. It is additionally essential to examine teachers' perceptions inside a particular setting since it is highly context-specific (Freeman \& Johnson, 1998). Although some researchers (Aliakbari \& Allahmoradi, 2012; Alimorad \& Tajgozari, 2016; Amiryousefi, 2015; Barzegar \& Afghari, 2015; Farvardin Koosha, 2011; Katooli \& Abdolmanafi-Rokni, 2015; Gilakjani \& Sabouri, 2017; Rahimi \& Askari Bigdeli, 2016; Ramazani, 2013; Salimi \& Ansari, 2015) have so far studied teachers' perceptions about various aspects of 
language teaching in the context of Iran, no genuine research has been done regarding vocabulary instructions from teachers' point of views. Under such intents, the present study contributes to the formation of a better recognition of English language teachers in private language schools and discloses hidden areas of their approaches which cannot be easily studied through product oriented research methods.

\section{REVIEWING OF LITERATURE}

\section{A. Teachers' Perceptions and Classroom Practice}

Teachers' perceptions are used as an umbrella term to capture all abstract intellectual resources teachers bring with them into the milieu of the classroom. Borg (2003) characterizes teacher's perceptions as the covert intellectual aspect of teaching and it includes what teachers discern, believe, and think of their own works (Borg, 2003). Considering perception as a phenomenon that captures all intellectual resources including teachers' beliefs, Johnson (1994) maintains that there are three basic assumptions to teachers' beliefs: 1) Teachers' beliefs affect how they perceive things and how they judge things. 2) Teachers' beliefs determine how they will use teaching information in the classroom environment. And 3) Understanding of teachers' beliefs is critical for the improvement of teaching effectiveness and programs in teacher education. It is supported by educational research that belief system determines teachers' instructional decisions and their classroom performances to a great extent. The belief system which incorporates previous experience, prior expectation and habits, serves as a screen, and acts upon all aspects of teachers' decision making, including adopting particular teaching approaches or activities and selecting certain instructional materials over others (Pajares, 1992; Richardson, 1996). Despite the fact that the basis of classroom practices is a logical system of beliefs, past research has failed to place attention on teachers' perceptions, thinking and beliefs regarding their teaching practices (Garner, 1987) and only recently have language teachers' thought processes begun to shed light on their classroom performance and generate discussion on language teachers' preparation program and their paths of learning to teach. Borg (2003) posits that teaching decisions are the result of complex and conflicting perceptions related to language, learning in general and second language learning in particular, and students. Teachers' perceptions and beliefs are significant issues since they implicitly or explicitly impact teaching practices (Borg, 2015-2005).

\section{B. Researching Teachers' Perceptions and Previous Studies in Second Language}

Considering the significance of teaching as "the center of all education and educational reform" (p.14), Shulman (1987) points to the partial and incomplete nature of the process-product approach to investigate epistemological issues like teachers' cognitions. Various studies into both teacher's and learners' belief systems have been conducted by researchers and scholars (Borg, 2003; Horwitz, 1988; Peacock, 1999; Vásquez\& Harvey, 2010). A considerable lot of the reviews indicate vast contrasts amongst teachers' perceptions frameworks, making it vital to keep on researching their impression of second language learning and teaching. As indicated by Borg (2009), teachers' perceptions inquiry deals with exploring hidden side of teaching and teachers' mental lives. Reviewing teachers' perceptions studies discloses the accumulation of research around grammar, reading, and writing while other curricular domains like vocabulary and speaking are not well studied (Borg, 2009). Reviewing these studies uncovers two principle viewpoints: what teachers believe about the teaching of grammar (e.g. Berry, 1997; Borg, 2005; Johnston \& Goettsch, 2000; Schulz, 1996), and what they know of grammar (e.g. Andrews, 1999).A group of studies dealt with L2 teacher knowledge about reading (e.g., Meijer, Verloop, \& Beijaard, 2001; Tercanlioglu, 2001) have contributed substantially to such studies. Reviewing the literature on teacher knowledge revealed three significant studies (e.g., Katz, 1996; Tsui, 1996) about how L2 writing is taught. In summary, it can be concluded that there are similarities among the so far mentioned group of research in the way that teachers' beliefs affect their instructional behavior and what factors may influence teacher knowledge development. These studies also indicate the methodological preferences of teachers while teaching. Although research in language teaching has rarely paid attention to the importance of curricular aspects like vocabulary especially in Iran, Gerami and Noreen (2013) explored four EFL teachers' perceptions of vocabulary teaching through a qualitative inquiry. Results demonstrated that participants possessed acceptable knowledge and firm self conviction about how vocabulary ought to be informed; nonetheless their practices were far from their strong beliefs.

\section{Theoretical and Conceptual Framework of the Study}

To succeed vocabulary teaching, language teachers need to know and employ appropriate strategies to enhance vocabulary learning (O' Malley\& Chamot, 1990). So far variety of teaching and learning models have been introduced and brought to the field to improve the quality of vocabulary teaching and learning. Irrespective to the extent of the degree of success and power of the introduced models, what can be construed as the main intentions of all are that vocabulary teaching ought to be dynamic and ought to consider the different measurements of the mental lexicon (Seal,1987).Considering such intentions and since teaching and learning vocabulary demands to hold an extensive variety of skills (Zimmerman, 1997) and requires to take advantage of memory strategies (Schmitt \& Carter; 2000), Shen's (2003) conceptualized model of vocabulary teaching and learning strategies, which is a dynamic continuum of various methodologies of vocabulary and originally adopted from Oxford and Crookall's (1990) model, has been found suitable and selected by the researchers of this study to draw up a complete picture of teachers' perceptions of vocabulary teaching. Generally, the adopted model includes two basic categories of contextualization and 
decontextualization which are two extremes and in between vocabulary learning strategies can be taught in a pendulum fashion. Listening, speaking, reading, and writing, as skills for lexical input and output, are located in one extreme (i.e. contextualization) and word list, flashcards, and conventional use of dictionary as measurements to improve the mental lexicon are in the other extreme (i.e. decontextualization). In between other strategies like word grouping, word/concept association, imagery, keyword, physical response, physical sensation, and semantic mapping are used with tendency to remain in between or moving towards each extreme according to the recognition of the needs of the learners. The combination of all these strategies is also utilized to reestablish words.

\section{Statement OF THE PROBLEM}

Words are the most essential components in a target language since our knowledge of a language is remarkably formed by the lexical items we learn (Nation, 2011; Schmitt, 2000). Notwithstanding the centrality of vocabulary in second language teaching and learning, vocabulary is considered as the greatest source of problems of language learners (Segler, Pain, \& Sorace, 2002) and conceivably language teachers face complications in how to apply their instructional decisions in order to be understandable for their students while teaching vocabulary. Scholarly literature documenting teachers' instructions regarding vocabulary is so meager that it appears few scholars are aware of the stream of teachers 'constant decisions in the milieu of classroom and how they organize and put vocabulary in their lesson plans (Borg, 2009). The same story seems to be true as "in Iran, vocabulary is one of the most challenging issues in language teaching and what teachers do in their classes and include in their lesson plans to teach vocabulary are not clearly documented or studied" (Gerami \&Noreen, 2013, p.1533).Teachers almost do not fully include this curricular area in their practices and only limit their instructions to some personal strategies. Therefore, students coming in private language institutes do not usually have a profound knowledge of vocabularies and their repertoires of lexical items are not rich enough to let them understand or generate utterances communicatively (Gerami \& Noreen, 2013).Although insufficient reliable evidence and solid confirmation do exist to demonstrate that vocabulary today is a noteworthy appeal with regards to ELT in Iran, the failure of Iranian English language learners, as the yield results of private language institutions, to comprehend basic sentences or to pass on their communicative goals through straightforward words might be considered as a consistent sign to construe that ELT, in Iranian private language schools, experiences some conceivable issues. A long with these lines, one of the objectives of any teaching system is inevitably teaching strategies to students on how to learn and to help them act autonomously in their learning process (Eslami Rasekh \& Valizadeh, 2004; Jahangard, 2007). Although no particular training has so far been given to teachers in this respect, they teach vocabulary mostly through various traditional approaches and mainly based on their own perceptions of vocabulary learning and teaching (Gerami \&Noreen,2013). Under such circumstances it appears essential to understand teachers' perceptions and practices of vocabulary teaching (Borg, 2003).

\section{RESEARCH QUESTIONS}

The main objective of this investigation is to discover English language teachers' practices and perceptions of vocabulary teaching in Iranian private language schools and to see whether their perceptions are in alignment with their practices. The subsequent queries were generated to accomplish the objectives of the inquiry:

1. What are Iranian EFL teachers' perceptions of vocabulary strategy instruction?

2. What strategies are practiced by Iranian EFL teachers in private language schools while teaching vocabulary?

\section{Methodology}

\section{A. Research Design}

A basic qualitative design (Merriam \& Tisdell, 2015) was adopted to perform the research. This was because the majority of the research in connection to teachers' perceptions are inside the interpretivist worldview and, therefore, the researchers are usually encouraged to adopt a qualitative data collection approach (Van Driel, Beijaard \&Verloop, 2001).

\section{B. Participants}

A purposeful sampling approach (Patton, 2002) was adopted due to its rationale and influence which "lie in selecting information-rich cases for study in depth" (p.230). Four competent informants who could provide in-depth information, understand the complexity of their work and elaborate on their own experiences were selected. They were chosen from among of 127 English language teachers were given numbers for secrecy. See table 1 for more information about the participants' background information. 
TABLE 1:

\begin{tabular}{lllll} 
& \multicolumn{4}{c}{ GENERAL BACKGROUND INFORMATION OF THE PARTICIPANTS } \\
Participants' Number & 1 & 2 & 3 & 4 \\
\hline Gender & Male & Male & Female & Female \\
\hline Age & 47 & 39 & 41 & PhD \\
\hline Degree of Education & $\mathrm{PhD}$ & $\mathrm{MA}$ & Student & \\
& & & 13 & \\
\hline Teaching experience & 11 & 14 & Part-time University & Official employee of the \\
\hline Organization & Official employee of & Official employee of the ME & lecturer & ME \\
\hline Proficiency Document & University & TELTS and MSRT & IELTS & IELTS
\end{tabular}

\section{Instruments and Data Collection Procedure}

In addressing the trustworthiness of the data relevant to the purpose of the study, multiple qualitative data collection techniques including interviews, observations, and stimulated recall interviews were used to elicit the participant's perspectives and experiences of vocabulary teaching. All employed interview questions were adopted originally from Borg (1998) and Nelms (2001). Generally, each of the participants experienced four classroom observations as well as nine interviews including: one pre-observation interview, four post-observation, and four stimulated recall interviews during the whole time of the research which took about two months. In all observations, the researcher took on the role of non-participant observer (Alwright \& Bailey, 1991) and followed the guidelines about ethics proposed by Christians (2000) all through the entire course of the research. Participant teachers had to plan in such a way to be able to cover the course (Four Corners, Level 4, Units 6-9) within the time limits as determined, by language school, for them. In general, minutes allocated for data collection included 25 up to 40 minutes for each pre-observation interviews, 90 minutes for each observations, and 10 to 20 minutes (depending on the amount of time needed to clarify ambiguities observed in the classroom) for stimulated recall interviews which were conducted immediately after classroom observations, Mackey and Gass, 2005. To conduct a fruitful stimulated recall interview, each participant was first provided with adequate guidelines. Second, audio records adjacent to field notes were used as the reference to stimulate participants' memories for more clarifications (Schepens, Aelterman \& Van Keer, 2007)). Participants' responses were all carefully recorded, transcribed and analyzed in the same fashion as for other interviews.

\section{Analysis and Results}

Strauss and Corbin's (1990) coding system, comprising three systematic steps of open coding, axial coding, and selective coding, was used. In open coding phase, verbatim transcripts of the audio recorded interviews and observation field notes of participants' instructional practices were carefully read several times. To construct responsive categories, data was then broken down into units and each unit was assigned a code or label for ease of access. In the axial coding phase and through interpretation and reflection on meaning (Merriam \& Tisdell, 2015), the researchers went back over all notes to identify which codes could go together. This process went on through the entire transcripts which then was put into a merging operation to obtain merged records of the categories reflecting the recurring regularities and patterns of this study.

To answer the first research question which was concerned with the participants' perceptions of vocabulary instruction, the researchers employed a semi-structured in-depth pre-observation interview including five open-ended questions adopted from Borg (1998). Summary of findings for research question one indicates that all participants believed in the positive role of strategies in teaching of vocabulary and notably believed in selective strategies as follows: synonym, definition, translation, memorization, reading aloud practice, constant use of dictionary, nonmnemonic elaboration technique, additional reading materials, and word formation. Participants' actual beliefs (i.e. recommended strategies for teaching and learning vocabularies) did not show perfect, according to the components of the agreed upon conceptual model in this study, by that the vacuum of contextualization strategies and skills was an obvious issue. Table 2 illustrates categories and Table 3 shows some evidences found for research question One.

To answer the second research question, multiple data collection instruments including: one pre-observation interview, four classroom observations, and four stimulated recall interviews were used for each of the participants. Themes relevant to both teachers' perceptions about vocabulary instruction and their real practices in the classroom have been reported, as this fashion of organization was helpful to attain the best results pertinent to the questions of the study. The questions researchers in this study employed were mainly adopted from Borg (1998).Summary of findings for research question two indicates that all participants employ a group of selective strategies for teaching vocabulary in their classrooms. These strategies are as follows: synonym, antonym, definition, exemplification of words in sentences, translation, memorization, note taking, and reading words aloud in classroom. Such strategies in terms of degree of emphasis or frequency of application in the classroom were somehow different from those stated by participants as their actual beliefs and some predominant strategies (e.g. Constant use of dictionary, non-mnemonic elaboration techniques, additional reading materials, word formation, etc.) were missed to be employed in participants' real practice in the classroom. As the emerged themes from data are concerned, participants showed another belief (i.e. adopted belief) which is compatible with what they did in the classroom. According to the themes emerged from the data, participants have not received any focused and special education about vocabulary teaching in higher and teacher education 
institutions before being graduated and a perfect competency in this respect has not been reflected in both their beliefs and practices in this study. Consequently, they might be in need for assistance. For example few language teachers do know how to teach a second language to children and this might require special training and education based on the learners' age and level of proficiency. Vocabulary teaching; therefore, is not an exception and for an optimal teaching condition teachers need more focused training in this respect and other similar curricular areas of language teaching. Table 4 exhibits the categories of EFL teachers' practices in vocabulary instruction in the classroom.

\section{DISCUSSIONS AND CONCLUSIONS}

Participants' showed positive perceptions and understanding of vocabulary teaching through their accentuation on the significance and helpful role of vocabulary teaching strategies. Emphasizing on the application of selective strategies, participant teachers proved that they somehow believe in a dynamic way of teaching in which the employment of several strategies and skills can provide learners with better chances to learn vocabulary (Zimmerman, 1997). It was found plausible to look at participants' perceptions from the focal point of Shen's (2003) conceptual dynamic continuum model of various methodologies for vocabulary teaching and learning which is basically grounded on Oxford and Crookall's (1990) model. According to the emerged data from pre-observation interviews, participants' perceptions did not capture skills like listening, speaking, reading, and writing to a sufficient extent and they reflected more interest and tendency of application on strategies like translation, memorization, constant use of dictionary, word formation, etc. which almost emphasize on retention and are usually considered as decontextualized strategies).Many scholars and experts (e.g., Coady, 1993; Joe, Nation, \& Newton, 1996; Nation \& Coady, 1988) have brought to light the certain outcomes of employing contextualization strategies enabling learners to get target words as well as their contextual implications, perceive the meaning of them or retrieve them in long-term memory, make recognitions with respect to their appropriacy and use. Since predominant contextualization strategies were not brought in light by participants both in their beliefs and practices, it might be concluded that this is one of the possible area that requires modification in terms of both declarative knowledge and practical training. Such failures, in the context of language schools, may be traced in other factors as well and the researchers of this study do not strongly attribute shortcomings to the knowledge of EFL teachers since such issue requires more investigation. It almost seems that teachers' deviations from their actual beliefs were not totally found in their inability of vocabulary teaching. It looks as if policies implemented in the language schools, intentionally are towards more time economization and this has been mainly found to be responsible that teachers neglect contextualized vocabulary teaching and focusing on different aspects of vocabularies through various decontextualized approaches. Although this might appear as irrelevant to the aim of this study, the issue has been reported as it was found marginally in the process of the study through emerging themes. Considering that some approaches in vocabulary teaching requires communicative activities, cultural practice, practicing vocabulary through different skills, various feedbacks and interactions, etc., the importance of time and failure of participant teachers to cover relevant skills and activities then become apparent since. Grounded on the theoretical and conceptual framework of this study, and notwithstanding the participants' knowledge of vocabulary teaching, they need assistance and modification in some areas (e.g. contextualization strategies, language skills and approaches relevant for teaching vocabulary in contextualized fashion, collaborative and involvement strategies, pragmatic based tasks and activities with more focus on listening and speaking, etc.).

\section{IMPLICATIONS AND SUGGESTIONS}

Results of this study can be informative for both language teachers and teacher education programs. It might also be beneficial for stakeholders in private sectors to include recent findings in their curriculum and especially in professional development courses to improve their programs. Participant teachers' practices proved that there is a gap between what they know about vocabulary teaching and what they actually do in classroom. Therefore, it seems that teachers need to get familiar with the requirements of real time situations with respect to how ideally vocabulary might be taught and the issues and practical problems that might hinder teaching what they want to teach. Despite the fact that teachers are outfitted with a pleasant actual perception as for how vocabulary can be taught effectively, they should be liberated from their second traditional and adopted convictions and comprehend the significance of language skills and other areas of language teaching in the advancement of vocabulary. Assistance might be provided with more focus on vocabulary teaching in a practical way through practicum courses to be realized and then be preceded through in-service trainings and professional development programs. Teachers must reflect on their works and those of their associates and turn out to be long life learners to have the capacity to examine weaknesses. Every one of these attempts may happen in higher and teacher education centers as they are in charge of information transmissions. The second implication might be fruitful for EFL language institutions which need to consider how to create reasonable functional in-service training courses relevant to the objectives of their textbooks with considering the instructional needs and wants of both teachers and learners. Therefore, it may be useful to for all intents and purposes include EFL instructors in workshops important to the goals of their works and familiarizing them with late research discoveries, fruitful methodologies of teaching in vocabulary teaching as a curricular area. Along these lines, EFL teachers would become interested enough to explore their own works as reflective teachers who will then keep up the policy of teachers as lifelong learners in all aspects of 
their vocations. This research has been done within the interpretivist worldview with a qualitative methodology and then can be only adduced in comparable settings to the one research was led. Therefore, researchers are recommended to study the same subject with different research methodologies (e.g., mixed method, survey, etc.) to build the generalizability of the discoveries for better and large-scope policy and educational decision makings.

TABLE 2:

FINDINGS WITH RESPECT TO THE FIRST RESEARCH QUESTION IN BRIEF

\begin{tabular}{|c|c|c|c|}
\hline $\begin{array}{l}\text { Strategy/ } \\
\text { Core category based on } \\
\text { Shen's (2003) Model }\end{array}$ & $\begin{array}{l}\text { Strategy/ Category based } \\
\text { on Shen's (2003) Model }\end{array}$ & $\begin{array}{l}\text { Category } \\
\text { (Techniques/Activities/ } \\
\text { strategy ) }\end{array}$ & Example themes Emerged from data \\
\hline \multirow[t]{3}{*}{$\begin{array}{l}\text { Decontextualized } \\
\text { strategies }\end{array}$} & Word lists & $\begin{array}{l}\text { Translation } \\
\text { Synonyms } \\
\text { Antonyms } \\
\text { Memorization } \\
\text { Making notes } \\
\text { Mnemonic }\end{array}$ & $\begin{array}{l}\text { Using known words to understand unknown words- } \\
\text { Persian equivalents - similar word - alternative } \\
\text { expression - opposite word - writing notes with } \\
\text { your own words, visual recall through notes, } \\
\text { replacement word -simple known word, - using } \\
\text { sounds and images to better retain words, etc. }\end{array}$ \\
\hline & Flashcards (Gloss) & $\begin{array}{l}\text { Definition } \\
\text { Simple explanation }\end{array}$ & $\begin{array}{l}\text { Explaining unknown words- describing difficult } \\
\text { words - using more simple words - unfolding hard } \\
\text { words - writing words and their meanings on cards, } \\
\text { writing down definitions, etc. }\end{array}$ \\
\hline & Dictionary use & $\begin{array}{l}\text { Word-analysis } \\
\text { Word formation } \\
\text { Dictionary }\end{array}$ & $\begin{array}{l}\text { Different forms of words - parts of speech- verbs - } \\
\text { adjectives- adverbs- nouns - prefixes- suffixes- } \\
\text { word stem, using dictionary, understanding word } \\
\text { aspects through dictionary, etc. }\end{array}$ \\
\hline \multirow[t]{2}{*}{$\begin{array}{l}\text { Semi-contextualized } \\
\text { strategies }\end{array}$} & $\begin{array}{l}\text { Word grouping, } \\
\text { Association }\end{array}$ & $\begin{array}{l}\text { Chunk } \\
\text { Words' relationships } \\
\text { Related words }\end{array}$ & $\begin{array}{l}\text { Words used in similar fields- words from the same } \\
\text { family- Connotative words- relating words to each } \\
\text { other - group of words related to one word, story } \\
\text { making with related words, etc. }\end{array}$ \\
\hline & $\begin{array}{l}\text { Visual imagery, Aural } \\
\text { imaginary, Physical } \\
\text { response, Physical } \\
\text { sensation, Semantic } \\
\text { mapping }\end{array}$ & $\varnothing$ & $\begin{array}{l}\varnothing \\
\text { No themes were emerged from data }\end{array}$ \\
\hline $\begin{array}{l}\text { Contextualized } \\
\text { strategies }\end{array}$ & $\begin{array}{l}\text { Reading, } \\
\text { Speaking, } \\
\text { Listening, } \\
\text { Writing (Skills) }\end{array}$ & $\begin{array}{l}\text { Read aloud } \\
\text { Contextual clues } \\
\text { More context } \\
\text { Non-Mnemonic Elaboration } \\
\text { Lexical out put } \\
\text { Lexical input } \\
\text { Lexical use }\end{array}$ & $\begin{array}{l}\text { Audio lingual context, inferring meanings, } \\
\text { guessing meanings, more context through more } \\
\text { reading material, meaningful clarification of words, } \\
\text { clarifying the words through examples, less } \\
\text { reliance on memory through elaboration, lexical } \\
\text { input and output, lexical use, listening practice, } \\
\text { writing words in sentences, using words in oral } \\
\text { production to link them with other words, etc. }\end{array}$ \\
\hline
\end{tabular}

TABLE 3:

EVIDENCE FOUND FOR RESEARCH QUESTION ONE

\begin{tabular}{|c|c|}
\hline $\begin{array}{l}\text { Category } \\
\text { (Techniques/Activities/ } \\
\text { strategy ) }\end{array}$ & Some Example Evidences From Participants \\
\hline Synonym & $\begin{array}{l}\text { "In most cases, using simple equivalents or synonyms are better to be used before translating the unknown } \\
\text { word" (Participant 1). }\end{array}$ \\
\hline Definition & $\begin{array}{l}\text { "I believe that defining words not only leads learners to better comprehension, but also it would be effective } \\
\text { for learning more words in a the minimum context of that definition" (Participant 2) }\end{array}$ \\
\hline Translation & $\begin{array}{l}\text { "Usually translation works better since it removes misconceptions. Learners cannot understand whatever } \\
\text { definitions and explanations given for help, and more that we as teachers do not have more time to spend on } \\
\text { every single elements of the course and we should cover it within the time limit determined for us" } \\
\text { (Participant } 3 \text {, Dec.2016). }\end{array}$ \\
\hline Memorization & $\begin{array}{l}\text { "Memorization of words is an easy approach for students to apply. It does not take the time of the classroom } \\
\text { and students only need to focus." (Participant 4, Dec.2016). }\end{array}$ \\
\hline Reading aloud practice & $\begin{array}{l}\text { "Reading aloud helps learners learn better through involving their other senses and it helps memory at the } \\
\text { time of speaking to remember words and their pronunciations" (Participant 1, Dec, 2016). }\end{array}$ \\
\hline Constant use of dictionary & $\begin{array}{l}\text { "I always advise my students not to leave down dictionary and constantly put your eyes on the definitions, } \\
\text { examples, function of words, pronunciation keys, etc. To help students become independent to find out the } \\
\text { meaning of words and practice on their own, dictionary use is the best strategy since lots of opportunities } \\
\text { will be created and new word formations as well as new vocabularies are incidentally come into view for } \\
\text { learners" (Participant, 2). }\end{array}$ \\
\hline Non-Mnemonic & "Teachers must meaningfully clarify for learners how the words are different or used. Clarifying the \\
\hline Elaboration Technique & $\begin{array}{l}\text { problems of students through examples can help them learn words better. With little reliance on memory } \\
\text { through elaboration and semantic mapping students can learn sooner and better" (Participant, } 3 \text { ). }\end{array}$ \\
\hline $\begin{array}{l}\text { More reading } \\
\text { (More context) }\end{array}$ & $\begin{array}{l}\text { "More reading materials are needed for learners to increase: their guessing ability of meanings in different } \\
\text { contexts, greater number of words in different topics, their familiarity with pragmatics and use of the words. } \\
\text { Reading can help learners more than other skills" (Participant, 4). }\end{array}$ \\
\hline Word formation & $\begin{array}{l}\text { "To help learners know wider range of vocabulary as well as their usages teachers need to help learners to } \\
\text { deal with such cases in a dictionary"(Participant } 3 \text { ). }\end{array}$ \\
\hline
\end{tabular}


TABLE 4:

FINDINGS WITH RESPECT TO THE SECOND QUESTION IN BRIEF

\begin{tabular}{lll}
\hline $\begin{array}{l}\text { Strategy } \\
\text { Core category based on Shen's (2003) } \\
\text { Model }\end{array}$ & $\begin{array}{l}\text { Strategy (Category) based on } \\
\text { Shen's (2003) Model }\end{array}$ & Categories emerged from interviews, field notes, etc. \\
\hline $\begin{array}{l}\text { Decontextualized } \\
\text { strategies }\end{array}$ & Word lists & $\begin{array}{l}\text { Synonym } \\
\text { Antonym } \\
\end{array}$ \\
& Flashcards (Gloss) & $\begin{array}{l}\text { Definition } \\
\text { Translation } \\
\text { Memorization } \\
\end{array}$ \\
& & Making Notes \\
\hline Contextualized strategies & Read aloud & Reading texts and stories aloud in classroom \\
& Non-Mnemonic & Exemplification of words in sentences \\
\hline
\end{tabular}

\section{REFERENCES}

[1] Aliakbari, M., \& Allahmoradi, N. (2012). On Iranian School Teachers' Perceptions of the Principles of Critical Pedagogy. International Journal of Critical Pedagogy, 4(1), 154-171.

[2] Alimorad, Z., \& Tajgozari, M. (2016). A Comparison of Iranian High School Teachers' and Students' Perceptions of Effective English Teachers. SAGE Open, 6(4), 2158244016679212.

[3] Allwright, D., \& Bailey, K. M. (1991). Focus on the language classroom: An introduction to classroom research for language teachers: Cambridge: Cambridge University Press.

[4] Amiryousefi, M. (2015). Individuality in higher education: The use of the multiple-mnemonic method to enhance ESP students' vocabulary development (depth and size) and retention. Applied Research English Language, 4(1), 45-58.

[5] Anderson, R., \& Freebody, P. (1981). Vocabulary knowledge. In 1. T. Guthrie (Ed.), Comprehension and teaching: Research reviews (pp. 77-117). Newark. DE: International Reading Association.

[6] Barzegar, Z., \& Afghari, A. (2015). School Teachers' and University Professors' Perceptions: Teaching Culture in Focus. Journal of Applied Linguistics and Language Research, 2(5), 98-113.

[7] Bachman, L. F., \& Palmer, A. S. (1996). Language testing in practice: Designing and developing useful language tests (Vol. 1), Oxford: Oxford University Press.

[8] Berry, R. (1997). Teachers' awareness of learners' knowledge: The case of metalinguistic terminology. Language Awareness, 6(2-3), 136-146.

[9] Bialystok, E. (1990). Communication strategies: A psychological analysis of second-language use: . Oxford: Basil Blackwell.

[10] Borg, S. (1998). Teachers' pedagogical systems and grammar teaching: A qualitative study. TESOL quarterly, 32(1), 9-38.

[11] Borg, S. (2003). Teacher cognition in language teaching: A review of research on what language teachers think, know, believe, and do. Language teaching, 36(2), 81-109.

[12] Borg, S. (2005). Experience, knowledge about language and classroom practice in teaching grammar. Applied linguistics and language teacher education, 325-340.

[13] Borg, S. (2009). Language teacher education. Education, 7(1), 107-120.

[14] Borg, S. (2015). Teacher cognition and language education: Research and practice: London: Bloomsbury Publishing.

[15] Chamot, A. U. (2005). Language learning strategy instruction: Current issues and research. Annual review of applied linguistics, $25,112-130$.

[16] Chamot, A. U., \& O'Malley, J. M. (1996). The cognitive academic language learning approach: A model for linguistically diverse classrooms. The Elementary School Journal, 96(3), 259-273.

[17] Cohen, A. D. (1998). 4 Strategies and processes. Interfaces between second language acquisition and language testing research, 90-111. Cambridge: Cambridge University Press.

[18] Coady, J. (1993). Research on ESL/EFL vocabulary acquisition: Putting it in context. In T. Huckin, M. Haynes, \& J. Coady (Eds.), Second language reading and vocabulary learning, 3-23. Norwood, NJ: Ablex.

[19] Creswell, J. W. (2007). Designing and conducting mixed methods research, Thousand Oaks, CA: Sage Publications.

[20] Debreli, E. (2011). Use of diaries to investigate and track pre-service teachers' beliefs about teaching and learning English as a foreign language throughout a pre-service training program. Procedia-Social and Behavioral Sciences, 15, 60-65.

[21] Eslami-Rasekh, Z., \& Valizadeh, K. (2004). Classroom Activities Viewed from Different Perspectives: Learners' Voice and Teachers' Voice. TESL-EJ, 8(3), 1-13.

[22] Farvardin, M. T., \& Koosha, M. (2011). The role of vocabulary knowledge in Iranian EFL students' reading comprehension performance: Breadth or depth. Theory and Practice in Language Studies, 1(11), 1575-1580.

[23] Freeman, D., \& Johnson, K. E. (1998). Reconceptualizing the knowledge-base of language teacher education. TESOL quarterly, 32(3), 397-417.

[24] Garner, R. (1987). Metacognition and reading comprehension: Ablex Publishing. Corporation, Norwood, NJ.

[25] Gerami, M. R., \& Noordin, N. B. (2013). Teacher cognition in foreign language vocabulary teaching: A study of Iranian high school EFL teachers. Theory and Practice in Language Studies, 3(9), 1531.

[26] Ghanizadeh, A., \& Jahedizadeh, S. (2015). An exploration of EFL learners' perceptions of classroom activities and their achievement goal orientations. International Journal of Research Studies in Education, 4(3), 33-45.

[27] Gilakjani, A. P., \& Sabouri, N. B. (2017). Teachers' Beliefs in English Language Teaching and Learning: A Review of the Literature. English Language Teaching, 10(4), 78-86.

[28] Green, J. M., \& Oxford, R. (1995). A closer look at learning strategies, L2 proficiency, and gender. TESOL quarterly, 29(2), 261-297.

[29] Harste, J. C., \& Burke, C. L. (1977). A new hypothesis for reading teacher research: Both the teaching and learning of reading is theoretically based. In P. D. Pearson (Ed.), Reading: Theory, research and practice, 32-40. 
[30] Horwitz, E. K. (1988). The beliefs about language learning of beginning university foreign language students. The Modern Language Journal, 72(3), 283-294.

[31] Jahangard, A. (2007). Evaluation of EFL materials taught at Iranian public high schools. ELT Journal, 9 (2), 130-150.

[32] Joe, A., Nation, P., \& Newton, J. (1996). Vocabulary learning and speaking activities. Paper presented at the English Teaching Forum.

[33] Johnson, K. E. (1994). The emerging beliefs and instructional practices of preservice English as a second language teachers. Teaching and teacher education, 10(4), 439-452.

[34] Johnston, B., \& Goettsch, K. (2000). In search of the knowledge base of language teaching: Explanations by experienced teachers. Canadian Modern Language Review, 56(3), 437-468.

[35] Katooli, S. H., \& Abdolmanafi-Rokni, S. J. (2015). A Comparative Analysis of Students' and Teachers' Perceptions of Effective Foreign Language Teaching in Iran. Journal of Applied Linguistics and Language Research, 2(8), 57-75.

[36] Katz, A. (1996). Teaching style: A way to understand instruction in language classrooms. In K. M. Bailey \& D. Nunan (Eds.), Voices from the language classroom: Qualitative research on language education, 57-87. New York: Cambridge University Press.

[37] Lincoln, Y.S., \& Guba, E.G. (1985). Naturalistic Inquiry, Vol. 75, 1st ed. Newbury Park, California: Sage Publications.

[38] Meijer, P. C., Verloop, N., \& Beijaard, D. (2001). Similarities and differences in teachers' practical knowledge about teaching reading comprehension. The Journal of Educational Research, 94(3), 171-184.

[39] Merriam, S. B. (1998). Qualitative Research and Case Study Applications in Education. Revised and Expanded from" Case Study Research in Education.": ERIC.

[40] Merriam, S. B., \& Tisdell, E. J. (2015). Qualitative research: A guide to design and implementation (4th ed). San Francisco, CA Jossey-Bass.

[41] Nation, I. S. P. (2011). Research into practice: Vocabulary. Language Teaching, 44, 529-539.

[42] Nation, P. \& Coady, J. (1988). Vocabulary and reading. In R. Carter \& M. McCarthy (Eds.), Vocabulary and Language Teaching, 97-110. London and New York: Longman.

[43] Nelms, J. L. (2001). A descriptive analysis of the uses and functions of sarcasm in the classroom discourse of higher education. Unpublished doctoral dissertation. University of Florida.

[44] O’Malley, J.M. \& Chamot, A.U. (1990). Learning Strategies in Second Language Acquisition. Cambridge University Press, Cambridge.

[45] Oxford, R., \& Crookall, D. (1990). Vocabulary learning: A critical analysis of techniques. TESL Canada Journal, 7(2), 09-30.

[46] Oxford, R. L. (2003).Language learning styles and strategies: an overview. GALA, 1-25.

[47] Pajares, M. F. (1992). Teachers' beliefs and educational research: Cleaning up a messy construct. Review of educational research, 62(3), 307-332.

[48] Peacock, M. (1999). Beliefs about language learning and their relationship to proficiency. International Journal of Applied Linguistics, 9(2), 247-263.

[49] Quinn Patton, M. (2002). Qualitative research and evaluation methods: Sage.

[50] Rahimi, A., \& Askari Bigdeli, R. (2016). Iranian EFL Teachers' Perceptions of Teacher Self-Disclosure. Iranian Journal of Language Teaching Research, 4(1), 83-96.

[51] Rahimi, M., \& Naderi, F. (2014). The relationship between EFL teachers' attitudes towards CLT and perceived difficulties of implementing CLT in language classes. International Journal of Applied Linguistics and English Literature, 3(3), 237-245.

[52] Ramazani, M. (2013). Teachers' Perceptions of Using English Textbooks for Iranian Technical and Vocational College Students. Procedia-Social and Behavioral Sciences, 70, 1748-1762.

[53] Richardson, V. (1996). "The role of attitudes and beliefs in learning to teach". In: Sikula, J.; Buttery, T.J. E Guyton, E. (eds.), Handbook of research on teacher education, 2. ed. Nova Iorque: MacMillan, 1996, 102-119.

[54] Salimi, A., \& Ansari, N. (2015). Learner autonomy: investigating Iranian English teachers' beliefs. Theory and Practice in Language Studies, 5(5), 1106.

[55] Schepens, A., Aelterman, A., \& Van Keer, H. (2007). Studying learning processes of student teachers with stimulated recall interviews through changes in interactive cognitions. Teaching and teacher education, 23(4), 457-472.

[56] Schmitt, N., \& Carter, R. (2000). The lexical advantages of narrow reading for second language learners. Tesol Journal, 9(1), 4-9.

[57] Schulz, R. A. (1996). Focus on form in the foreign language classroom: Students' and teachers' views on error correction and the role of grammar. Foreign Language Annals, 29(3), 343-364.

[58] Seal, B. (1987). Vocabulary builder 1. London: Longman.

[59] Segler, T. M., Pain, H., \& Sorace, A. (2002). Second language vocabulary acquisition and learning strategies in ICALL environments. Computer Assisted Language Learning, 15(4), 409-422.

[60] Shen, W.-W. (2003). Current trends of vocabulary teaching and learning strategies for EFL settings. Feng chia journal of Humanities and social sciences, 7(1), 187-224.

[61] Shulman, L. (1987). Knowledge and teaching: Foundations of the new reform. Harvard educational review, 57(1), 1-23.

[62] Strauss, A. L., \& Corbin, J. (1990). Basics of qualitative research (Vol. 15): Newbury Park, CA: Sage.

[63] Tercanlioglu, L. (2001). Pre-service teachers as readers and future teachers of EFL reading. Tesl-ej, 5(3), n3.

[64] Tsui, A. B. (1996). Learning how to teach ESL writing. In D. Freeman \& J.C. Richards (Eds.), Teacher learning in language teaching, 97-119. Cambridge, England: Cambridge University Press.

[65] Van Driel, J. H., Beijaard, D., \& Verloop, N. (2001). Professional development and reform in science education: The role of teachers' practical knowledge. Journal of research in science teaching, 38(2), 137-158.

[66] Vásquez, C., \& Harvey, J. (2010). Raising teachers' awareness about corrective feedback through research replication. Language Teaching Research, 14(4), 421-443.

[67] Woodrow, J. E. (1991). Teachers' perceptions of computer needs. Journal of research on computing in education, 23(4), 475496. 
[68] Zimmerman, C. B. (1997). Historical trends in second language vocabulary instruction. In J. Coady \& T. Huckin (Eds.), Second Language Vocabulary Acquisition. New York: Cambridge University Press.

Sara Mirzaie has already got her MA. in the field of Teaching English as a Foreign Language (TEFL) from Payame Noor University, Iran. She has 10 years teaching experience in private English language institutions. She is interested in areas such as teachers' belief and cognition, vocabulary teaching and learning, English language pedagogy, and teacher development, etc.

Fatemeh Hemmati is an associate professors at Payame Noor University of Tehran, Iran. She has published several books and are interested in the areas such as academic writing, teaching methods, and classroom discourse analysis.

Mohammad Aghajanzadeh Kiasi received the PhD degree in TEFL from Payame Noor University. He has been teaching English since 2000 and currently heads the English Department at Payame Noor University in Rasht, Iran. He has published several papers on English language teaching with specialization in EFL writing. 